にし，ホルマリンをふやしてゆくと，生成される XFH の含酸素 量が多くなる先の報告 ${ }^{10)}$ から推定される。p-キシレン，とくにエ チルベンゼンは $m$ ーキシレンにくらべて反応性がはるかに低いた め，キシレン異性体の反応率と同じ傾向を示す。

以上のよ5に, o-, m-, p-キシレンのホルマリンに対する反応 10) 黄, 谷垣, 高分子化学 12, 335 (1955).
性を利用し， $m$ ーキシンン・ホルムアルデヒド樹脂を生成させつ つキシレン異性体を分離することができる。

(昭和 31 年 4 月 1 日, 日化第 9 年会発表)

最後に本研究に際し，赤外線吸収スペクトル測定に協力してい ただいた武田薬品工業研究所の神尾氏，研究に援助を賜わった八 幡製鉄株式会社，松下電工株式会社当局に深い謝意を表する。

\title{
$m$-キシレン・ホルムアルデヒド樹脂と $1,3,5$-キシレノールとの反応性
}

(昭和 32 年 6 月 3 日受理)

\section{黄 慶 雲・小林 晨 三*}

既報1)の m-キシレン・ホルムアルデヒド樹脂とフェノールとの縮合硬化に引続き，1, 3, 5-キシレノールとの反応性に ついて検討を行った。1，3，5-キシレノールはフェノールにくらべて反応性が高く，ょり多くの不溶性硬化樹脂を生成し

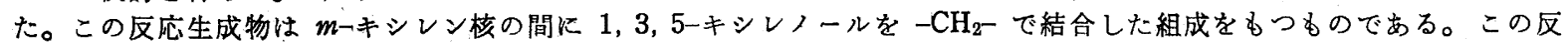
応性は反応温度, 反応時間, 反応触媒量, 反応モル比によって支配される。硬化の際, 硬化に達しなかった可溶部樹脂の

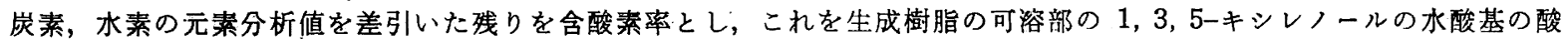

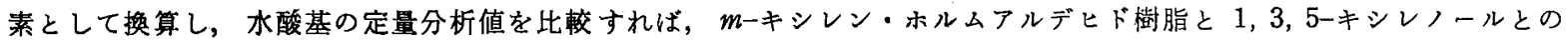
反応度合を知るのに有効であることがわかった。

\section{緒袞}

先に黄と谷垣 $\left.{ }^{1}\right)$ は $m$-キシレン・ホルムアルデヒド樹脂 (XFH と略す）が $m$-キシンンスルホン酸 $0.1 \%$ の触媒下でフェノール と縮合して硬化し，不溶性の樹脂になることを報告した。この不 溶性の硬化樹脂は $m$-キシンン核の間にフェノールが $-\mathrm{CH}_{2}-$ で 結合した組成であり，硬化反応は XFH 分子中に含まれる酸素率 が高いはど硬化し易い。これは XFH 分子中の含酸素因子，すな わち生成した XFH の $m$-キシンン核を結ぶエーテル, アセター ル結合がフェノールと後縮合して，硬化する役割をなすことを認 めた。

本報はフェノールと同じ 3 官能性で更に反応性の高い $1,3,5-$ キシレノールが XFH と縮合して硬化反応する際の反応温度, 反 応時間, 触媒量, 1,3,5-キシレノールとのモル比変化等の諸条件 を検討すると同時に，生成樹脂の含酸素量を測定して XFH の反 応度合を追跡するのを目的とする。

\section{実 験 の 部}

XFH の製法 温度計, カキマゼ装置, 冷却器を付した $500 \mathrm{cc}$ の三つロフラスコ内に m-キシレン $106 \mathrm{~g}$ ( $1 \mathrm{~mol}), 37 \%$ ホルマ

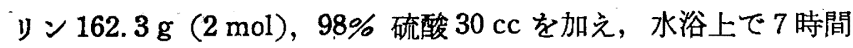
かきまぜて反応させる。反応後, 水層と $m$-キシンン・ホルムフ ルデヒド樹脂層とに分離しているので，その樹脂層を分液し，こ れにベンゼンを $100 \mathrm{cc}$ 添加して溶解し，数回水洗を行い，次に 水浴上で減圧下 $(10 \mathrm{mmHg})$ でペンゼンと末反応の $m$-キシンン を留去すると黄色の粘稠な油状樹脂をらる。収量 $78 \mathrm{~g}$, 樹脂の 含酸素率 $16.14 \%$ ，分子量 260 。以下本研究に拈ける $\mathrm{XFH}$ は本 法に準じて蔽造したるのである。

† 本報を「ホルムアルデヒド系树脂に関する研究(第 40 報)」 とする.

* 大阪市立大学理工学部高分子化学教室：大阪市北区南翏町.

1) 黄, 谷垣, 工化 58,517 (1955).
XFH と 1，3，5-キシレノールとの硬化法 径 $15 \mathrm{~mm}$, 長さ $150 \mathrm{~mm}$ の試験管に XFH $4.5 \mathrm{~g}, 1,3,5$-キシレノール(新たに蒸 留したもの) $2.5 \mathrm{~g}$ および $m$ 拉シンンスルホン酸 $0.004 \mathrm{~g}$ (X FH に対して $0.1 \%$ )を加兑，よくかきをぜた後，恒温油浴中で 所定の条件にしたがって縮合硬化させる。反応内容物は反応進行 とともに次第に粘度が上昇する。高温か, 触媒量が多い時には反 応内容物は急速に粘度が增加し, 膨張した硬化樹脂をうる。反応 後内容物をとり出しソックスレー抽出装置に入れ，ベンゼンで抽 出を行5。この抽出残留物の不溶部を硬化樹脂とした。可溶部は 水洗し，そのまま水蒸気蒸留を行い，塩化第二鉄ですはや水蒸気 蒸留の留出液に $1,3,5$-キシレノールが存在しない点まで水蒸気 蒸留を続けて行了。水蒸気蒸留の残留物はベンゼンで抽出し, 脱 水してベンゼンを留去すると，赤褐色の粘稠な餄状ないし固形状 の可溶性縮合樹脂を残す。すちろん未反応の XFH があれば一緒 に混在する。この可溶性樹脂について, 分子量, 樹脂中に結合し ている $1,3,5$-キシンノールの核の数を求め, 元素分析より炭 素, 水素以外の含有率を計算し, 含酸素量とした。以下に述べる 可溶部，不溶部の $\mathrm{XFH} \cdot 1,3,5$-キシレノール縮合樹脂は本方法 に準じて製造したものである。

可溶部の樹脂中の $1,3,5$-キシンノールの定量法は既報1)の方 法にしたがってこれを定量した。

既報性いて，XFH と 1,3,5-キシレノール，フェノールよ りあ反応性の低いアニリンとの反応の際に生成したキシンン・ホ ルムアルデヒドーアニリン樹脂中の $\mathrm{N}$ と O 含有率は互に反比例 の関係にあって，完全によく反応した場合の生成物は $\mathrm{C}, \mathrm{H}, \mathrm{N}$ の 3 元素のみによって構成され，Oが残ると Nの含有率が減少する ことを報告した。今回も同様にそれぞれの可溶部について炭素, 永素の元素分析を行い，その差引き残率を含酸素％とした。こ の含酸素 \% と分子量から生成樹脂の水酸基数を換算し，定量に よって求めた水酸基の数とを比較し， $\mathrm{XFH}$ と 1, 3, 5-キシレノ

2) 黄, 工化 58, 520 (1955). 
ールとの反応の度合を評価するものである。XFH と $1,3,5$-キ シレノールとの反忘過程 (第 1 図) 括よび元素分析より求めた含 酸素 \%による 1，3，5-キシレノールの水酸基の換算式は次のと おりである。

第 1 図

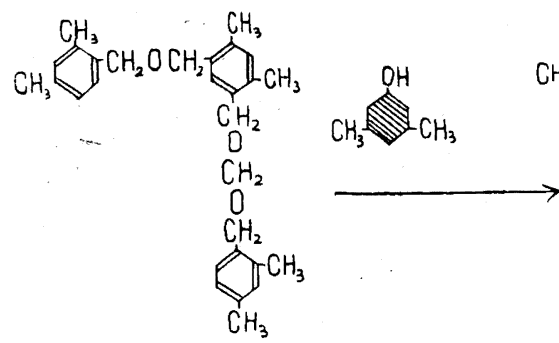

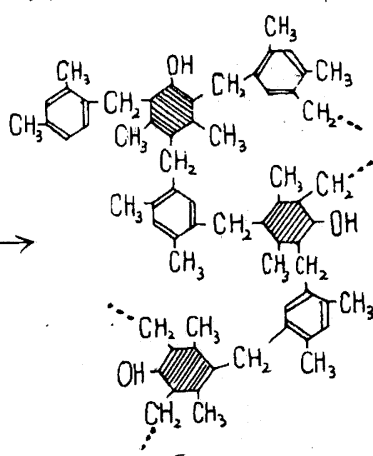
水酸基の数 $=\frac{\text { 樹脂の分子量 } \times \text { 元素分析より求めた } \mathrm{O} \%}{\text { 単位構造分子量 } \times 16}$

単位㩐造 $\cdots \cdots\left(\mathrm{CH}_{3}\right)_{2} \mathrm{C}_{6} \mathrm{H}_{2}-\mathrm{CH}_{2}-\mathrm{C}_{6} \mathrm{H}_{2}\left(\mathrm{CH}_{3}\right)_{2} \mathrm{OH}$

可溶部の生成樹脂をアセチル化によって定量した水酸基の数と 元素分析によってえられた水酸基の数を比較すると元素分析によ ってえた水酸基数の方が多いのは反応条件がゆるやかな場合に多 く，よく反応して硬化した部からえた可溶部の多くの場合は換算 值によく合致する。これらの差は未反応の $\mathrm{XFH}$ か，または第 2 図に示すようなエーテル結合が生成樹脂中に含まれ，水酸基とし て換算されたものである。

第 2 図

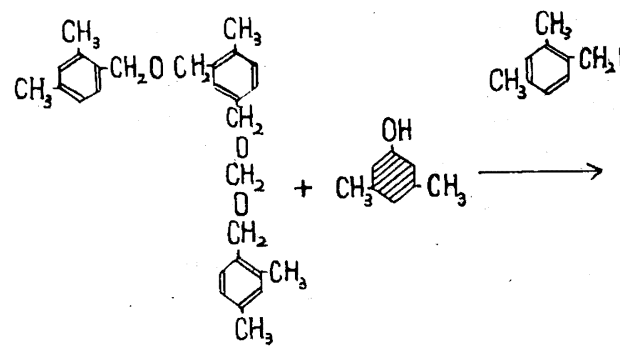

実験結果と考察

（1）反応温度のおよぼす影響 XFH（含酸素率 $16.14 \%$ )

そ 1,3,5-キシレノールを $m$-キシンンスルホン酸触媒下で硬化反 第 3 図

反応条件：XFH/1,3,5-キシレノール $\mathrm{X} / 1$ (モル比)，反応時間 $60 \mathrm{~min}$ $m$-キシンンスルホン酸 $0.1 \%$ XFH に対して ただし XFH の含酸素 $16.14 \%$

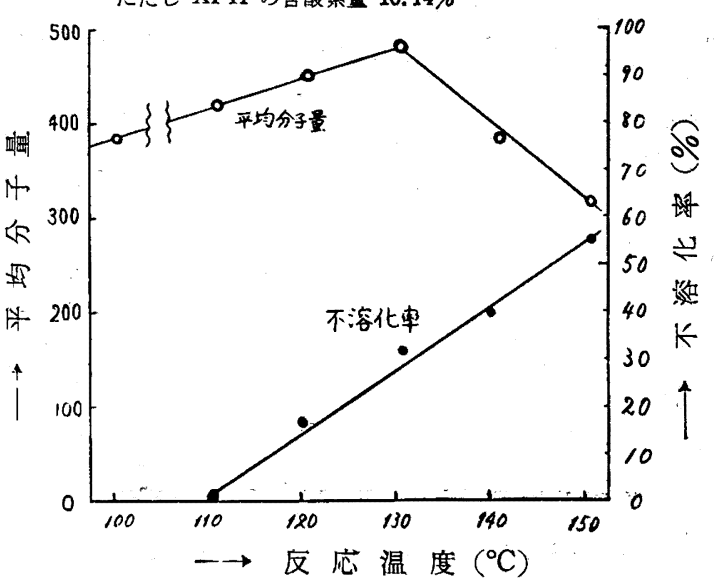

応する際の反応温度のおよぼす影響は第 3 図のとおりである。

$\mathrm{XFH}$ と 1,3,5-キシンノールを反応させ,ベンゼン抽出を行い, 不溶部を除いた可溶部の平均分子量は反応温度の上年ととすに上 升し， $110^{\circ} \mathrm{C}$ を越点ると不溶部を生成し始めるが，それですなお 平均分子量が上昇し， $130^{\circ} \mathrm{C}$ を越えると平均分子量が低下する。 一方, 硬化率は $110^{\circ} \mathrm{C}$ で硬化し始め, 直線的に上年する。 $150^{\circ} \mathrm{C}$ で 60 分間反応すると 56\% の硬化率を示した。とくにここで注 目されることは，ゲル化が始まっても可溶部の平均分子量はなお 上升しうるという井本, 大岩8)のゲル化理論に合致し, Flory の ポリ縮合におけるゲル化理論，すなわらゲル化と同時に可溶部の 分子量が低下するといらゲル化理論に一致しない，とい5ことで ある。

第 4 図は第 3 図の可溶部と不溶部の試料について炭素, 成素の 元素分析を行い, 炭素, 水素以外の含有されている元素を全部酸 素原子として換算した含酸素量と反応温度との影響を表わす。

$$
\text { 第 } 4 \text { 図 }
$$

反底件：XFH/1,3,5-キシレ)ール $m$-キシレシスルホン酸 $0.1 \%$ (XFH に対して) ただし XFH の含酸素量 $16.14 \%$

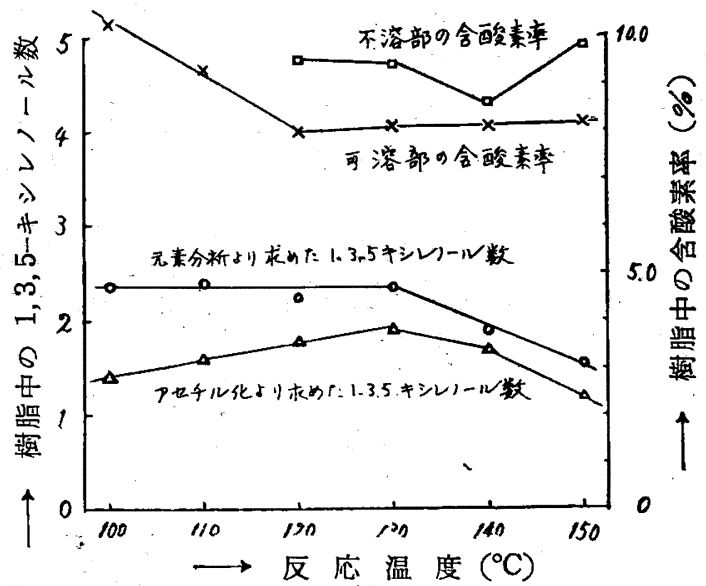

第 5 図

区応策件：XFH/1,3,5-キシレノール $=1 / 1$ 反応温度 $100^{\circ} \mathrm{C}$, 反応時間 $30 \mathrm{~min}$

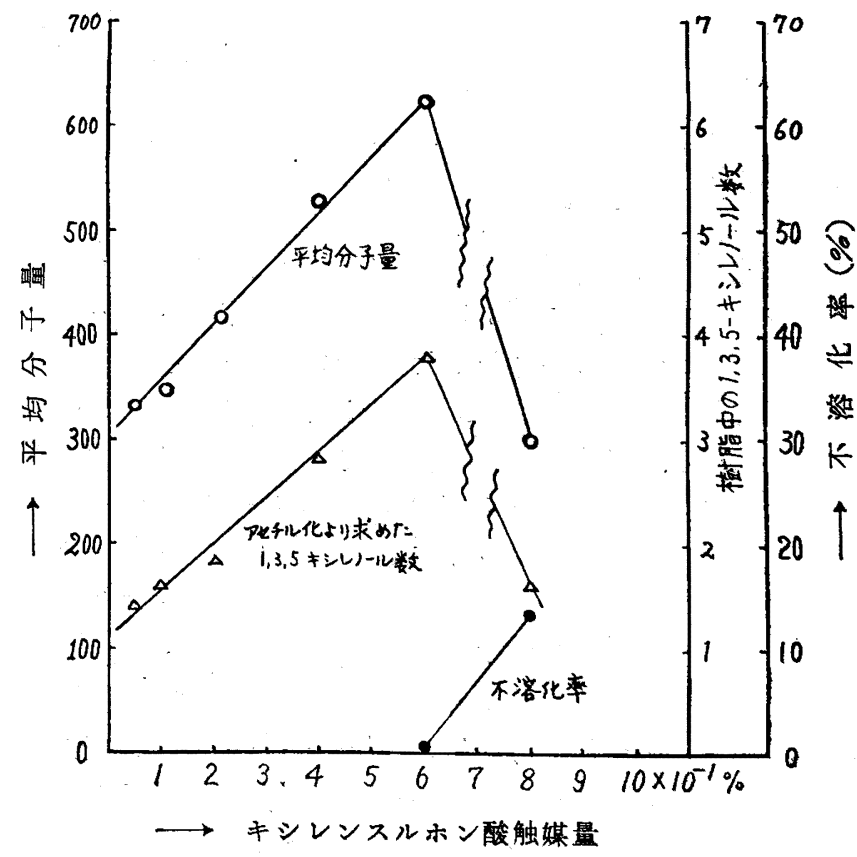

3) 井本, 大岩, 高分子化学 4, 102 (1947). 
可溶部に含まれている酸素量は 1,3，5-キシンノールと反応し て生成した XFH・1,3,5-キシレノール樹脂の中に:結合している 1,3,5-キシレノールの水酸基の定量値と, 元素分析より求めた計 算値を比較すると，反応温度の低い間は反応性が低いので，末反 応の XFH が相当残る可能性が大きく，逐次反応温度を上界さ せ，130 C を越光ると末反応の XFH が少なくなる。をた第 2 図 のよろにエーテル結合の残存量が少なくなるので第 1 四のような 理想構造に近づく。

（2）触媒量のおよぼす影響 触媒の扣よぼす影響が大きいの で出来るだけ不溶化しない低温 $\left(100^{\circ} \mathrm{C}\right)$ で短時間 (30 分間) 飞 反応を行った結果を第 5 図に示した。

触媒としての $m$-キシンンスルホン酸を $0.1 \%$ から $0.6 \%$ ま で上年させると平均分子量は触媒量に比例して顕著に上身し，不 溶化物が 生成し始める直前，すなわち触媒を $0.6 \%$ 使用した時 には分子量が 620 の最高値に達し， $0.6 \%$ を越えて $0.8 \%$ を用 いると不溶化が起り，一方，可溶部の平均分子量が顕著に低下す る。また生成樹脂中の $1,3,5$-キシレノールの数る平均分子量の增 加とともに上昇する。このように m-キシンンスルホン酸触媒は $\mathrm{XFH}$ そ 1,3，5-キシレノールとの縮合反応に重要な因子である。

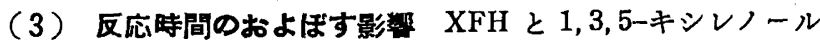
が縮合反応して不溶化し始める反応温度 $\left(120^{\circ} \mathrm{C}\right)$ で, 後縮合反応 を行う際の反応時間のおよ括す影響を示すと第 6 図のと括りであ る。

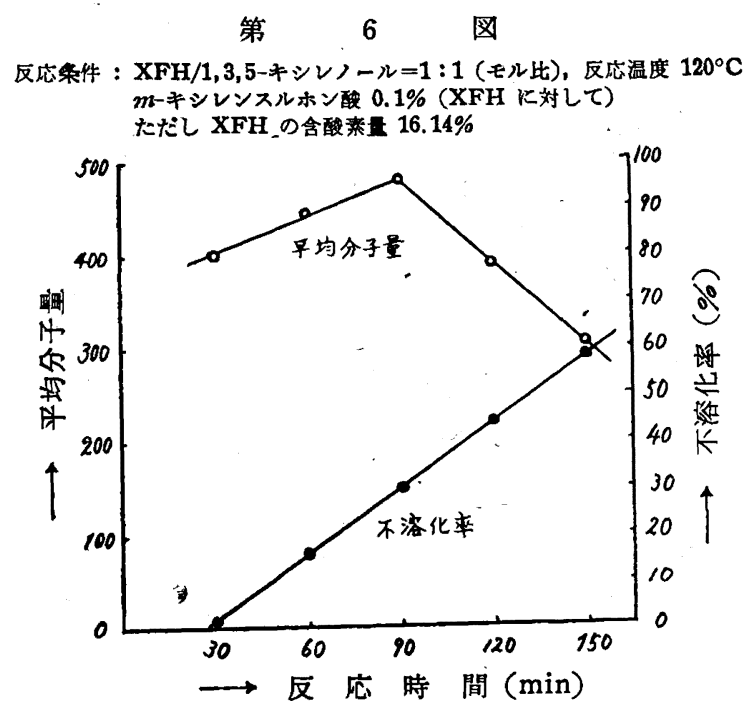

すなわち, 反応時間の增加とともに, 不溶化率は直線的に增加 し，150 分間で $60 \%$ に達する。しかるに可溶部の平均分子量注 反応時間 90 分間までの間は逐次上算し，90 分間を越えると急 激に低下する。この反応時間のおよ注す影響（第6 図）は反応温 度のおよ活す影響（第 3 図）とよく似ている。両者を比較すれば 反応温度が $110^{\circ} \mathrm{C}$ を越光ると反応時間の 30 分間は反応温度の $10^{\circ} \mathrm{C}$ の上䄯に相当する興味のある結果をえた。

反応時間のおよぼす可溶部の反応樹脂の含酸素率々樹脂中の 1 , 3,5-キシレノールの数との関係は第 7 四のと打りである。

可溶部の樹脂中の $1,3,5$-キシレノールの数は第 6 図の 平均分 子量と同じ傾向を示し，反応による不溶化が余り進んでいない間 は末反応の XFH か，またはエーテル結合が末反応のままで残っ ている率が多く，不溶化率が $30 \%$ を越光ると逐次 $m$-キシレン 核と 1,3,5-キシレノールが交互に結合した第 1 図の 理想構造の
第 7 目

区応来件：XFH/1,3,5-キシレノール $=1: 1$ (モル比), 区応温度 $120^{\circ} \mathrm{C}$ mーキシレンスルホン酸 $0.1 \%$ (XFH に対して) ただし XFH の含酸絮量 $16.14 \%$

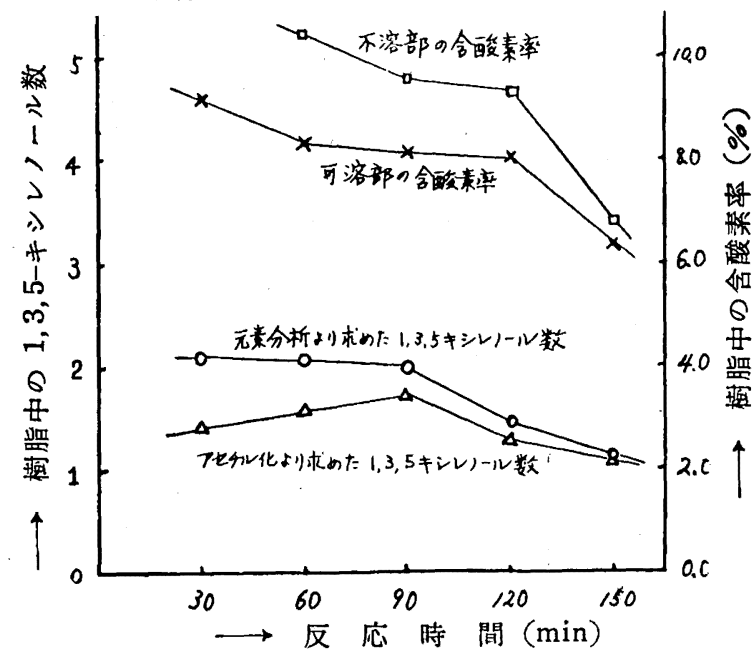

組成に接近している。とくに不溶化率が $60 \%$ の時の平均分子量 が約 300 で，アセチル化拈よび含酸素率より求めた 1,3，5-キシ レノールの数が 1.1〜1.2 であるので, この可溶部は主として, $\left(\mathrm{CH}_{3}\right)_{2} \mathrm{C}_{6} \mathrm{H}_{3} \mathrm{CH}_{2} \mathrm{C}_{6} \mathrm{H}_{2}\left(\mathrm{CH}_{3}\right)_{2} \mathrm{OH}$ なる 2 核体 (分子量) で構成され ると考える。これは XFH の末端キシレンか，または，2核体の $\mathrm{XFH}$ が 1,3,5-キシレノールと反応して m-キシレンと 1,3,5キシレノールで構成される 2 核のまま存在しているために起因す ると考える(第 8 図)。

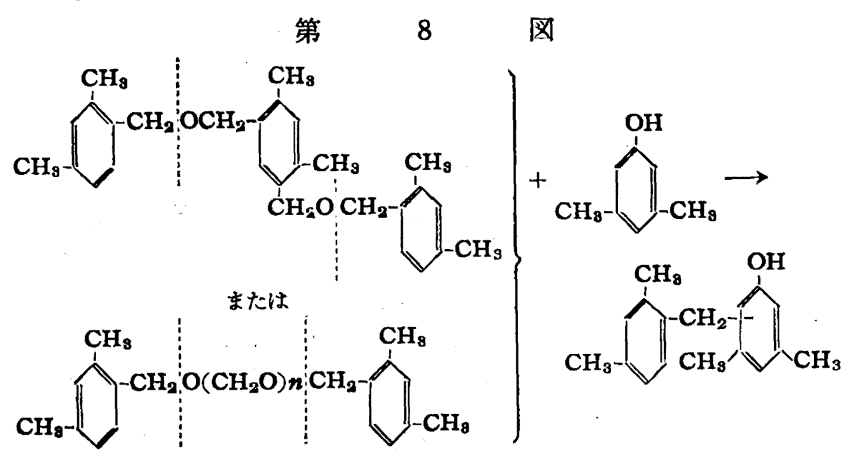

(4) 1,3,5-キシレノールの反応モル要化のおよぼす影警

XFHに対して 1,3,5-キシレノールの反応モル比を変化させて硬 化を行った際の影響は第 9 図に示すとおりである。

XFH $1 \mathrm{~mol}$ に対して 1,3,5-キシレノール $0.5 \mathrm{~mol}$ か, また は $0.75 \mathrm{~mol}$ を用いて縮合反応を行うと，可溶部の平均分子量る

$$
\text { 第 } 9 \text { 図 }
$$

反度件：XFH（含酸量 $17.13 \%$ )，反応温度 $100^{\circ} \mathrm{C}$, 反応時間 $30 \mathrm{~min}$

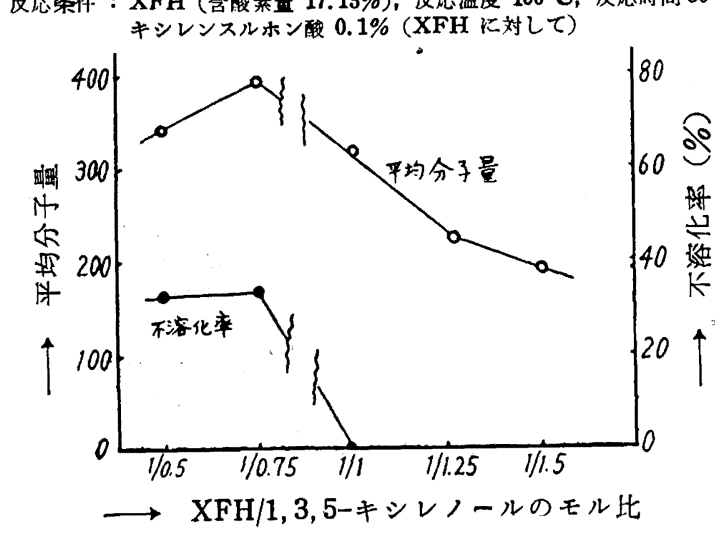


比較的に高く，不溶化部を容易に生成する。しかし XFH に対す る $1,3,5$-キシレノールのモル此を 1 以上にすると不溶化物を生 成せずして，可溶部の平均分子量む低下寸る。もちろん，触媒が 1,3,5-キシレノールのモル比の増加によって希釈されることも考 えられるが，それよりも 1,3,5-キシレノールを多量に用いると $\mathrm{XFH}$ が 1,3,5-キシレノールと反応し，平均分子量の低い間に， 用いた XFH が消費されて 1,3,5-キシレノールが残り，樹脂分 子の成長を妨げる。これが平均分子量低下の，おるな原因と考え る。これはポリ縮合系樹脂に見られる一般的な分子量低下と同じ 現象である。

第 10 図は第 9 図の XFH と 1,3,5-キシレノールとのモル比 の変化による反応により，生成した樹脂の含酸素率执よびアセチ ル化による樹脂中の $1,3,5$-キシレノールの定量值との関係を示 す。

$\mathrm{XFH}$ に対して 1,3,5-キシレノールとのモル比が 1 以下の間は 不溶化物を生成しても未反応の XFH が相当量残るので, 当然 セチル化によって求められた可溶部の 樹脂分子中の $1,3,5$-キシ レノールの数と, 元素分析によって求めた含酸素率から換算した 1,3,5-キシレノールの数との間に大きい距りが生じる。ところが 1,3,5-キシレノールとのモル比を 1 以上にするとこの両者の関係
第 10 図

反応条件：XFH (含酸来量 $17.13 \%$ ), 反応温度 $100^{\circ} \mathrm{C}$, 反地時間 $30 \mathrm{~min}$ キシレノールスルホン醀 $0.1 \%$ (XFH に対して)

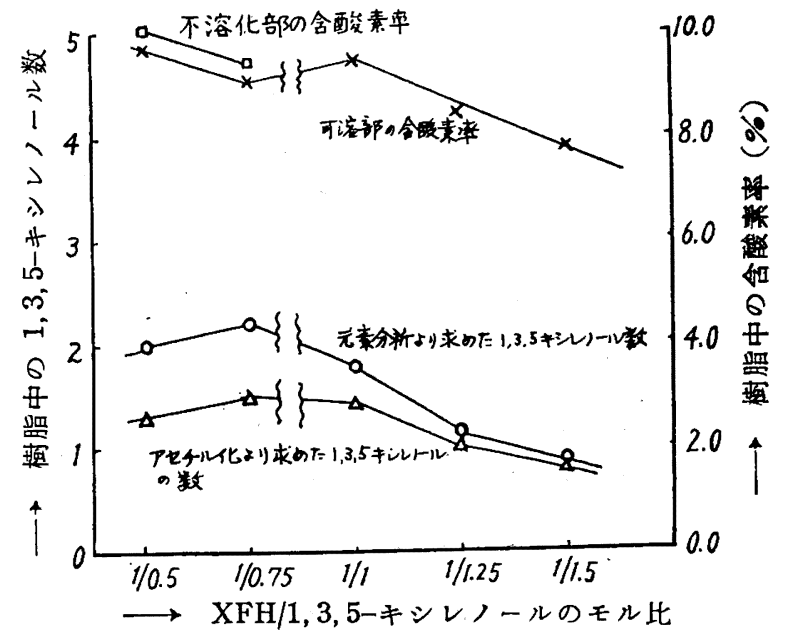

が次第に接近し $1.5 \mathrm{~mol}$ を用いた場合はほとんど一致に近い。 これは 1,3,5-キシレノールの過剩により，第8図のよ5に XFH と後縮合して 2 核体で反応が停止し，第 1 図の理想硬化構造の組 成になるためによると考える。

\section{$m$-キシレン・ホルムアルデヒド樹脂とノボラックとの反応性†}

(昭 和 32 年 6 月 3 日受 理)

\section{黄慶 雲・森 井 賢 作*}

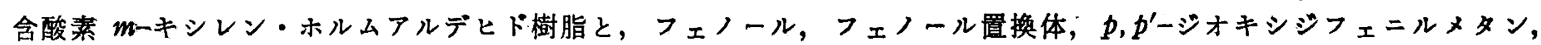
またはノボラックとを熱硬化さると 3 次元化した不溶性樹脂を生成する。低分子量のフェノール類よりす,ノボラックの 方がすみやかに 3 次元化した赫脂を5る。このノボラックとの硬化反応は著しく，反応時間，反応温度，反応触媒量に上 って影響されることを認めた。またこの レンテトラミンと異なった役割をはたすことをb合せて確認した。

\section{緒言}

mーキシレン・ホルムアルデヒド樹脂（以下 $\mathrm{XFH}$ と略す）は フェノール1)，1,3,5-キシレノール2) と反応して硬化し，3 次元 栈脂になることを報告した。これは $\mathrm{XFH}$ 中の $m$-キシンン核の エーテル結合, アセタール結合が酸触媒によって切れて, フェ 一ルのオルト, パラの三つの未反応官能位置と反応して, 硬化し たものと考える。したがってフェノール・ホルムアルデヒド樹脂 のノボラックも同様に次のよ5にその三つ以上の未反応官能位置 と反応すると考えられる。

本研究は 2 , または 3 官能基の各種のフェノール, および 4 官 能位置以上をすつ 2 核体, ノボラックと $\mathrm{XFH}$ との反応性を同 一条件で比較検討したところ第 1 表のような結果をえた。

第 1 表からわかるように 2 官能基の XFH は ルのような 2 官能基フェノールと反応しても不溶化物を生成しな

† 本報を「ホルムアルデヒド系樹脂に関する研究(第 41 報)」 とする。

* 大阪市立大学理工学部高分子化学教室：大阪市北区南扇町.

1) 黄, 谷垣, 工化 58,517 (1955).

2) 黄, 小林, 工化 60,1576 (1957).
第 1 表 XFH とフェノール類との硬化

\begin{tabular}{|c|c|c|c|c|c|}
\hline 反底物留 & $\frac{\mathrm{XFH}}{フ ェ ノ ー ル \text { 類 }}$ & $\begin{array}{l}\text { 不溶 } \\
\text { 华 } \\
(\%)\end{array}$ & $\begin{array}{l}\text { 可溶部 } \\
\text { の分子 } \\
\text { 量 }\end{array}$ & $\begin{array}{l}\text { 可溶部 } \\
\text { の } \\
\text { 数 }\end{array}$ & $\begin{array}{l}\text { 乳化開 } \\
\text { 㕷時间 } \\
(\mathrm{min})\end{array}$ \\
\hline フェノール & $1: 1$ & 4 & 500 & 1.99 & - \\
\hline o-クレゾール & $\|$ & 0 & 420 & 1.58 & - \\
\hline 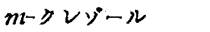 & $n$ & 39.0 & 260 & 0.59 & 为 40 \\
\hline かークレゾール & $" \prime$ & 0 & 390 & 1.49 & - \\
\hline 1,3,5-キシレノーネ & 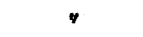 & 16.2 & 450 & 1.62 & 䄪 50 \\
\hline 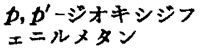 & " & 72.3 & 400 & 3.01 & 杓 15 \\
\hline $\begin{array}{l}\text { ノ゙ラック } \\
\text { * 試料が少量のた }\end{array}$ & 測定不能 & 90.3 & * & * & 为 10 \\
\hline
\end{tabular}

いが，3 官能基以上のものは容易にゲル化する。また分子量の小 さいフェノール類は不溶化樹脂の生成率が小さく，分子量の大き い2核体の $p, p^{\prime}$-ジオキシジフェニルメタンの場合は，ゲル化虫 が $72.3 \%$ ，さらにノホラックになると $90.2 \%$ といろ大さい值 を示している。このことは，分子量の大きいるのはど不溶化へ達 する時間が早いことを示している。次にフェノールについてみる と，不溶解性樹脂を除いた可溶部樹脂の分子量は 500 であり，可 溶部樹脂中の $\mathrm{OH}$ 基の数が 1.99 である。したがって分子量 500 について2 コのフェノール核が入っていることを示している。こ のことはXFH 中のエーテル結合またはアセタール結合の位置に 